\title{
THERAPEUTIC MANAGEMENT IN ULCERATIVE COLITIS
}

\author{
Roxana Călin, Petruț Nuță \\ Spitalul Universitar de Urgență Militar Central "dr. Carol Davila", București
}

\section{Rezumat}

Rectocolita ulcerohemoragică este o afecțiune inflamatorie cronică idiopatică a colonului, caracterizată printr-o inflamație superficială difuză care implică întotdeauna rectul, cu grade variate de extensie la nivelul colonulul proximal. Boala nu afectează intestinul subțire, deși un procent mic dintre pacienți pot prezenta o inflamație superficială limitată a ileonului terminal. Clinic, boala se manifestă prin rectoragii, tenesme rectale și diaree. Severitatea bolii se evaluează luând în considerație multipli factori, incluzând numărul de scaune, rectoragiile, aspectul endoscopic și efectele afecțiunii asupra calității vieții pacientului.

Tratamentul rectocolitei ulcerohemoragice este adaptat la severitatea puseelor de activitate a bolii, fără să existe un tratament universal eficient. Deciziile de tratament trebuie să se bazeze pe activitatea bolii (ușoară, moderată, severă) și distribuția acesteia (proctita, colită stânga, pancolită).

În cazul formelor de boală ușoare până la moderate limitate la rect și la pacienții cu colită stângă, baza tratamentului o constituie 5-aminosalicilații, care sunt foarte eficienți ca tratament topic (supozitoare, clisme, spume). Corticosteroizii sunt indicați la pacienții cu boală mai severă și în cazurile în care mesalazina a eșuat în inducerea remisiunii.

Recomandarea terapeutică de bază pentru rectocolita ulcerohemoragică extinsă ușoară până la moderată constă într-o terapie combinată cu 5-aminosalicilați administrați oral și topic, combinarea celor două forme de administrare dovedindu-se superioară utilizării unice a oricăreia dintre acestea. Utilizarea corticosteroizilor sistemici trebuie luată în considerare mai devreme pentru pacienții cu colită extinsă și / sau la care tratamentul cu 5-aminosalicilații a eșuat. Terapia adecvată pentru pacienții cu rectocolită ulcerohemoragică severă impune, în general, spitalizarea. În aceste cazuri, terapia cu corticosteroizi este încă standardul de aur. Dacă nu se observă nicio ameliorare sau simptomele se agravează după 72 de ore, se poate lua în considerare terapia convențională de linia a doua sau proctocolectomia. La pacienții refractari la corticosteroizi, precum și la pacienții cu rectocolită ulcerohemoragică severă, introducerea precoce a medicamentelor imunosupresoare poate fi eficientă pentru prevenirea recăderilor și a complicațiilor, cum ar fi megacolonul toxic. Fără îndoială, anticorpii anti-TNF au îmbunătățit opțiunile terapeutice disponibile pentru pacienții cu rectocolită ulcerohemoragică. Există, însă, un procent substanțial de pacienți care nu răspund la administrarea de anticorpi anti-TNF sau care pierd răspunsul la aceștia. Din fericire, pentru aceste cazuri, au fost dezvoltate noi clase de medicamente care se află în evaluare în diverse faze ale studiilor clinice. Pentru a ilustra heterogenitatea cazurilor de rectocolită ulcerohemoragică, prezentăm trei situații particulare.

Cuvinte cheie: rectocolita ulcerohemoragică, severitate, tratament 


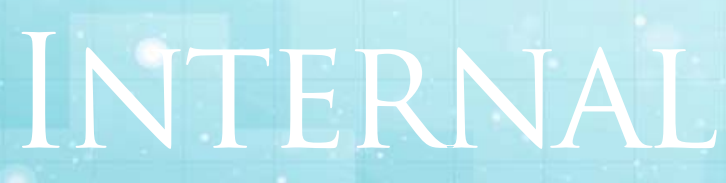

Clinical cases

\section{Abstract}

Ulcerative colitis is a chronic idiopathic inflammatory disorder of the colon, characterized by a diffuse continuous superficial inflammation that always begins within the rectum and affects the proximal colon to a varying extent. One typical feature of the disease is that it does not involve the small intestine. A small percentage of patients may present a superficial inflammation of the terminal ileum. Clinically the disease is associated with rectal bleeding and urgency, tenesmus, abdominal pain and diarrhea. In the assessment of the disease severity, various factors are used, including the frequency of bowel movements, rectal bleeding, laboratory tests, endoscopic extension and appearance and patient's quality of life.

The treatment of ulcerative colitis is adapted to the disease severity and to the individual patient, no treatment being universally effective. Treatment decisions should be based on disease activity (mild, moderate, severe) and distribution (proctitis, left-sided, extensive colitis). If mild to moderate inflammation is limited to the rectum and for left-sided colitis, the mainstay on the treatment are 5-aminosalicylates, which are highly effective as a topical treatment (suppositories, enemas, foams). Corticosteroids are indicated in patients with more severe disease, and in cases where mesalamine has failed in inducing remission.

For extensive mild to moderate ulcerative colitis, therapy recommendation consists of a combined therapy using oral and topical 5-ASA, which proved to be superior to single use of either. Use of systemic corticosteroids should be considered earlier for patients with extensive colitis and/or treatment failure. For patients with severe ulcerative colitis, hospitalization is generally required. In these cases, steroid therapy is still the gold standard. If there is no improvement in the first 72 hours after the initiation of treatment or symptoms are worsening, second-line conventional therapy must be attempted or proctocolectomy may be considered. In steroid-refractory patients, as well as in patients with severe ulcerative colitis, early introduction of immunosuppressive drugs may be effective during severe episodes, and for the prevention of complications, such as toxic megacolon. Without doubt, the introduction of anti-TNF antibodies have improved the therapeutic options available for patients with ulcerative colitis. But, there still is a substantial amount of patients not responding to anti-TNF antibodies or experiencing a secondary loss of response. Fortunately, for these cases, new classes of drugs have been developed and have been evaluated in early clinical trials.

To illustrate the heterogeneity of cases of ulcerative colitis, we present three particular situations.

Keywords: ulcerative colitis, severity, treatment. 
Ulcerative colitis is a chronic idiopathic inflammatory disorder of the colon, characterized by a diffuse continuous superficial inflammation that always begins within the rectum and affects the proximal colon to a varying extent. The disease is limited to the rectum in approximately a third of patients, to the left side of the colon in another third, and to the splenic flexure or beyond in the remaining third. One typical feature of the disease is that it does not involve the small intestine. A small percentage of patients may present a superficial inflammation of the terminal ileum.

Ulcerative colitis is usually diagnosed in late adolescence and early adulthood, although the diagnosis may be made at any age, and appears to affect both sexes equally ${ }^{(1)}$. Clinically the disease is associated with rectal bleeding and urgency, tenesmus, and diarrhea ${ }^{(2)}$, symptoms being present usually for a few weeks before the patient presents to the doctor ${ }^{(1)}$.

The diagnosis is based on a combination of clinical, biochemical, endoscopic, and histological investigations. In order for the diagnosis to be establisned, every patient should have a biochemical assessment with full blood count, inflammatory markers (Creactive protein [CRP]), electrolytes, liver enzymes, and a stool sample for microbiological analysis ${ }^{(3)}$.

Stool specimens should be obtained to exclude common enteric pathogens, and especially $C$ difficile. When suspecting ulcerative colitis, ileocolonoscopy with a minimum of two biopsies from the inflamed regions should be obtained ${ }^{(3)}$. The exception to this rule is severe colitis, in which case, due to the increased risk of bowel perforation, complete ileocolonoscopy is not usually recommended.

\section{Severity assessment}

In the assessment of the disease severity, various factors are used, including the frequency of bowel movements, rectal bleeding, laboratory tests, endoscopic extension and appearance and patient's quality of life ${ }^{(2)}$. Mild disease is typically considered to be characterized by fewer than 5 bowel movements per day and, not affecting in a negative way daily life.

On the other hand, moderate to severe disease is characterized by more frequent bowel movements (up to 10 per day), with bleeding, affecting daily activities, like patients' attendance at work or school.

Among objective clinical features, the most useful inpredisting the severity of the disease are bloody stool and frequency, body temperature, and heart rate ${ }^{(1)}$. As for the laboratory markers, the widely used acute phase C-reactive protein is not as useful in ulcerative colitis as it is in Crohn's disease for the assessment of disease activity ${ }^{(1)}$. Among the stool markers, the most used are faecal calprotectin and lactoferrin.

Taking into consideration the macroscopic extent at colonoscopy, ulcerative colitis is classified into proctitis (limited to the rectum), left sided colitis (the lesions limited to the splenic flexure) and extensive colitis (extending proximal to the spenic flexure)(table 2). Granularity, vascular pattern, ulceration, and bleeding and/or friability are endoscopic features predictive for disease severity ${ }^{(1)}$, bleeding and friability being included within the Mayo score for ulcerative colitis (table 3 ).

The extension of the lesions evaluated at colonoscopy may underestimate the extent of disease as compared with histology ${ }^{(1)}$. Therefore, biopsies are necessary to determine the real extent of colonic 


\section{INTERNAL}

\section{Clinical cases}

inflammation. A minimum of two biopsies from at least five sites around the colon, including the rectum and the ileum should be obtained, in any patient suspected of ulcerative colitis, in order to achieve a proper dignosis $^{(1)}$.

\section{Therapeutic management}

The treatment of ulcerative colitis is adapted to the disease severity and to the individual patient, no treatment being universally effective. Treatment decisions should be based on disease activity (mild, moderate, severe) and distribution (proctitis, left-sided, extensive colitis).

If mild to moderate inflammation is limited to the rectum and for left-sided colitis, the mainstay on the treatment are 5aminosalicylates, which are highly effective as a topical treatment (suppositories, enemas, foams). Corticosteroids are indicated in patients with more severe disease, and in cases where mesalamine has failed in inducing remission.

For extensive mild to moderate ulcerative colitis, therapy recommendation consists of a combined therapy using oral and topical 5ASA, which proved to be superior to single use of either. Use of systemic corticosteroids should be considered earlier for patients with extensive colitis and/or treatment failure.

For patients with severe ulcerative colitis, hospitalization is generally required. In these cases, steroid therapy is still the gold standard. If there is no improvement in the first 72 hours after the initiation of treatment or symptoms are worsening, second-line conventional therapy must be attempted or proctocolectomy may be considered. In steroid-refractory patients, as well as in patients with severe ulcerative colitis, early introduction of immunosuppressive drugs may be effective during severe episodes, and for the prevention of complications, such as toxic megacolon.

Without doubt, the introduction of anti-TNF antibodies have improved the therapeutic options available for patients with ulcerative colitis. But, there still is a substantial amount of patients not responding to anti-TNF antibodies or experiencing a secondary loss of response. Fortunately, for these cases, new classes of drugs have been developed and have been evaluated in early clinical trials.

\section{Therapeutic options in ulcerative colitis}

- 5-aminosalicylates (5-ASAs): sulphasalazine or mesalazine. Given either orally or rectally, are usually the first treatment option for mild or moderate ulcerative colitis. For patients with mild or moderately active proctitis the preferred initial treatment is a mesalamine 


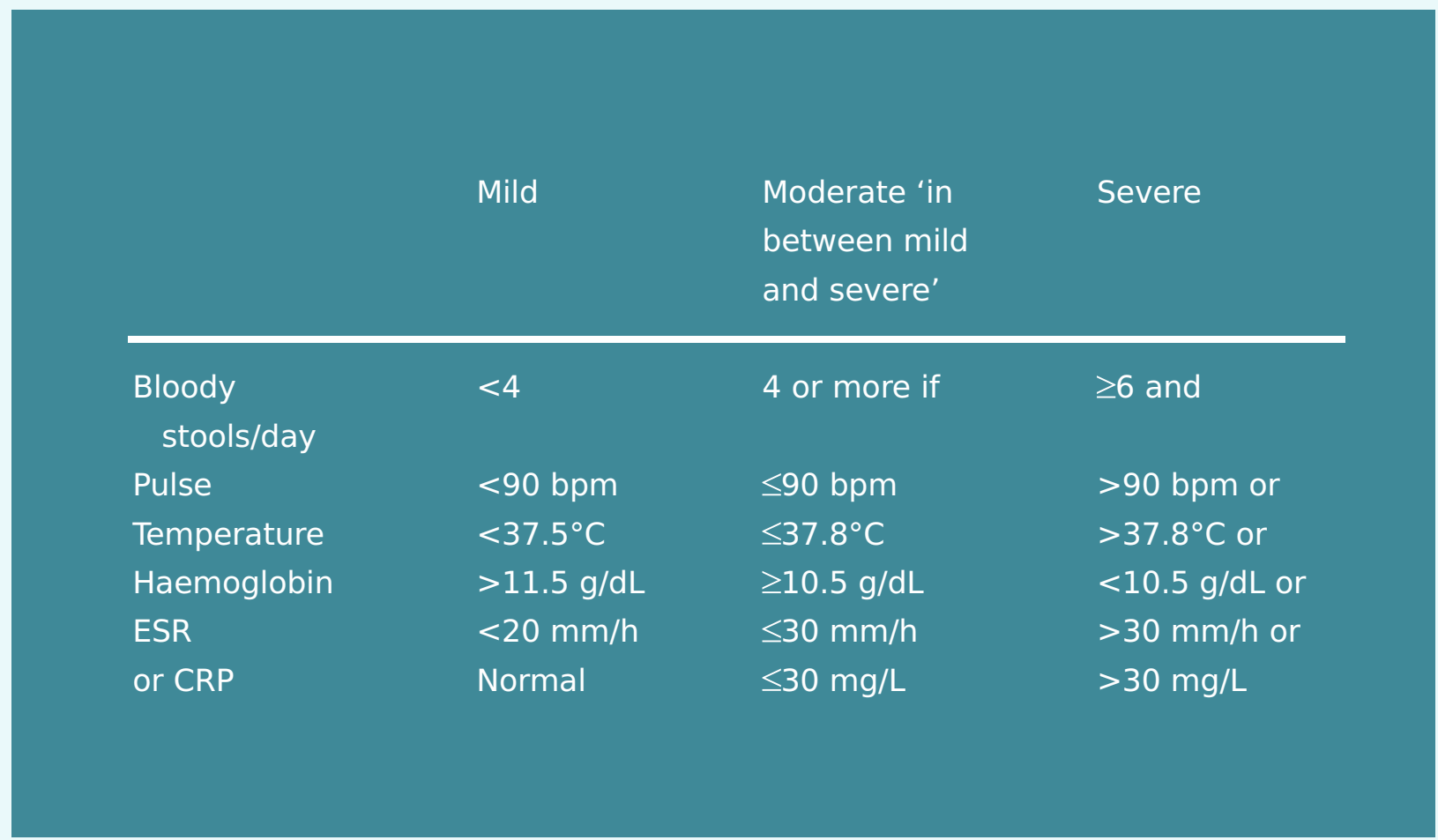

Table 1. Disease activity in ulcerative colitis *adapted from Truelove \& Witts ${ }^{(4)}$

Distribution Description

Proctitis

Involvement limited to the rectum [i.e proximal extent of inflammation is distal to the recto-sigmoid junction]

Left-sided

Involvement limited to the proportion of the colon distal to the splenic flexure [analogous to 'distal' colitis]

Involvement extends proximal to the splenic

Extensive flexure, including pan-colitis

Table 2. Distribution of UC * adapted from Silverberg et $\mathrm{al}^{(5)}$ 


\section{INTE}

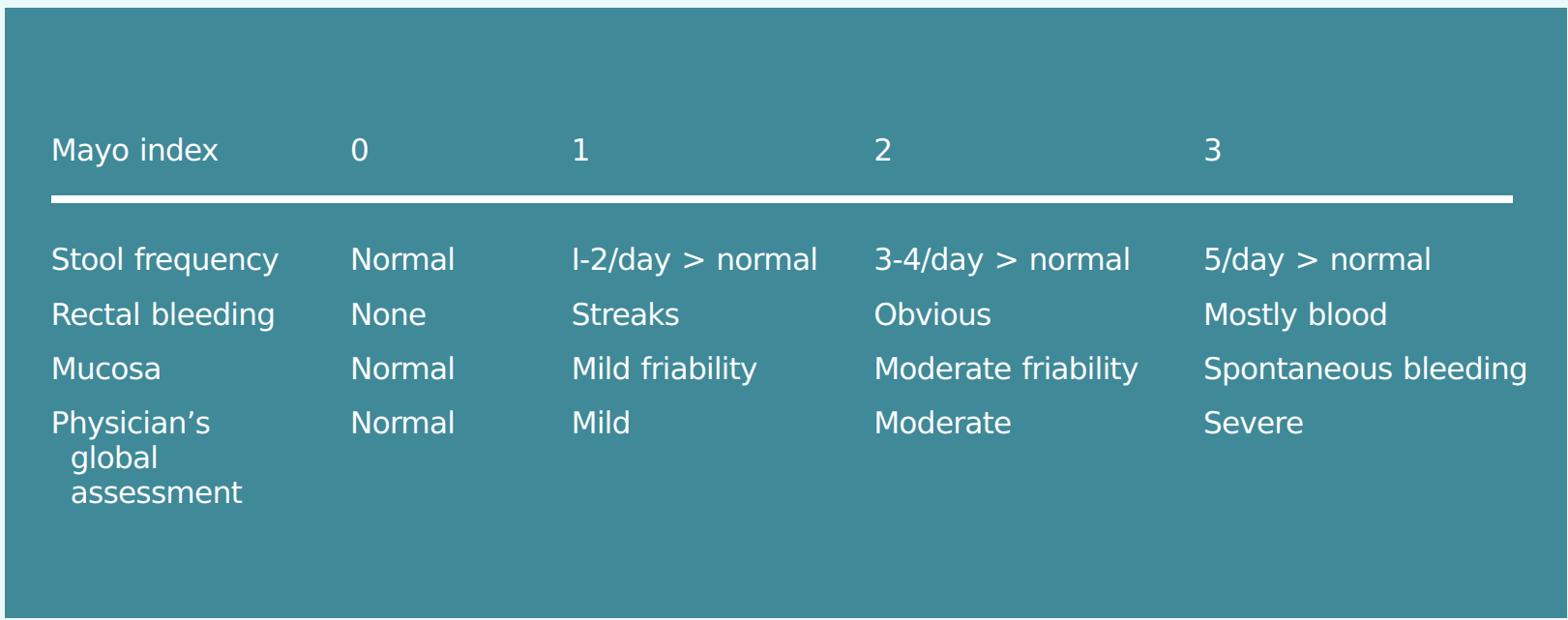

Table. 3. Mayo score for ulcerative colitis * adapted from ${ }^{(13)}$

suppository given once daily ${ }^{(1)}$, while cases with mild to moderately active left-sided ulcerative colitis should be treated with an aminosalicylate enema combined with oral mesalamine ${ }^{(1)}$

- Corticosteroids, orally, as an injection, rectally, or intravenously, are usually given to help with moderate to severe UC symptoms. Steroids are not intended for long-term use, because of the risk of dependency or resistance; they are best suited for short-term control of ulcerative colitis symptoms and disease activity ${ }^{(2)}$; Budesonide is a corticosteroid with lower systemic bioavailability, presenting a more favorable safety profile.
- Immunomodulators - cyclosporin, given orally or injected, these medications suppress the body's immune response being useful in cases where the symptoms are not succesfuly controlled or reoccur after the corticosteroids are stoped.

- Biologic agents used for the treatment of moderate to severe UC include the tumor necrosis factor inhibitors infliximab, adalimumab, and golimumab, and the integrin inhibitor vedolizumab. Given injectable, this class of drugs suppresses the immune system to reduce inflammation and is usually used for patients who have not responded to conventional therapy. The introduction of biologic, antitumor necrosis factor alpha (anti-TNF $\alpha$ ) 
therapies has been a great progress un the management of patients with inflammatory bowel diseases that are refractory to conventional treatments ${ }^{(6)}$. However, not all the patients respond to these drugs, some loose their response over time, or are intolerant to these treatments ${ }^{(7)}$

- Probiotics are being tried taking into consideration the fact that inflammatory bowel disease is associated with a complex interplay between microbes and the immune system, leading to an abnormal inflammatory response in genetically susceptible individuals. Fecal microbiota transplantation may be another method to increase the proportion of participants achieving clinical remission in ulcerative colitis ${ }^{(8)}$. However, the number of studies is small and the quality of evidence is usually low, and there is uncertainty about the adverse events.

\section{Activity-Adapted Therapy}

The factors influencing treatment decisions should be disease activity (mild, moderate, severe) and endoscopic distribution of the lesions (proctitis, left-sided, extensive colitis).

\section{Patients with Mild to Moderate Activity}

- In patients with mild to moderate inflammation that is limited to the rectum, the first-line therapy consists of topical treatment with mesalamine. The usual dosage is $1-\mathrm{g}$ mesalamine suppositories given once daily. Patients who fail to respond to this treatment require the addition of oral prednisolone ${ }^{(1)}$.
- For mild to moderate disease thet is limited to the left-sided colon, the first line therapy consists of a combination of topical mesalamine enemas or foams $1 \mathrm{~g} /$ day and oral mesalamine (>2 g/day). If after two weeks of treatment there are no results, systemic steroids need to be given ${ }^{(11)}$.

- For extensive mild to moderate ulcerative colitis, therapeutic recommendation consists of a combination of oral and topical mesalamine, which is superior to single use of either. Patients with extensive colitis and/or treatment failure need to be considered earlier for the use of systemic corticosteroids ${ }^{(12)}$.

\section{Severe Ulcerative Colitis}

- Patients with severe ulcerative colitis generally require hospitalization and appropriate investigations in order to confirm the diagnosis and exclude enteric infection.

- Steroid therapy is considered the gold standard for this patients. An initial intravenous dose of corticosteroids of $1 \mathrm{mg} / \mathrm{kg}$ shoud be given.

- Other measures in addition to IV steroids include: intravenous fluid and electrolyte replacement to correct and prevent dehydration and electrolyte i mbalance, subcutaneous prophylactic low-molecular-weight heparin to reduce the risk of thromboembolism, nutritional support if the patient is malnourished, blood transfusion to maintain a haemoglobin above 8-10 g/ $\mathrm{dl}^{(1)}$.

- If no improvement is seen or symptoms are worsening after $72 \mathrm{~h}$, second-line conventional therapy or proctocolectomy may be considered. In this 


\section{Clinical cases}

$\mathbf{A}$

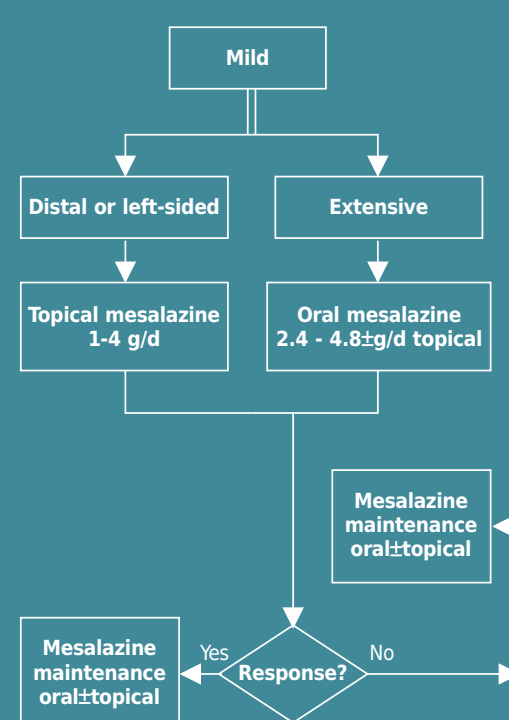

4

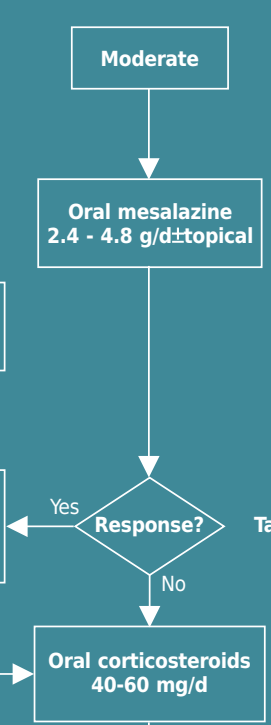

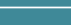

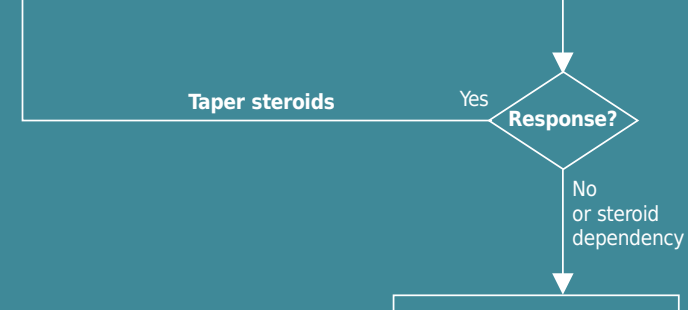

Azathioprine $2.5 \mathrm{mg} / \mathrm{kg}$ and/or* Infliximab $5 \mathrm{mg} / \mathrm{kg}$ (0, 2, 6 weeks) or (0, 2, 6 weeks) or
* Adalimumab 160-80 mg subcutaneous

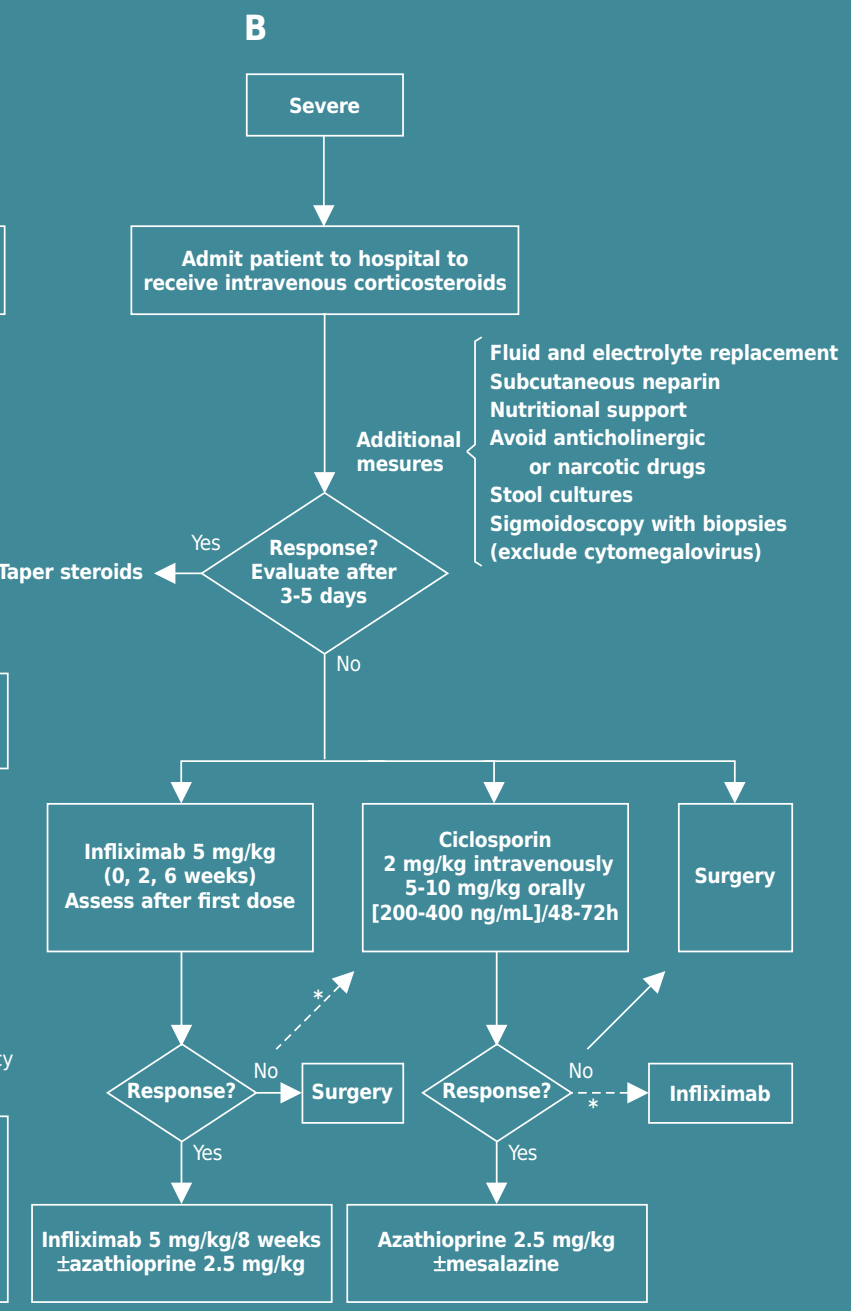


case, patients need to be cared for by a multidisciplinary team, consisting of gastroenterologists and surgeons specialized in abdominal surgery.

- To avoid proctocolectomy, treatment options include the calcineurin inhibitors cyclosporine and tacrolimus, and also the anti-TNF antibodies. All of these treatment options are considered similarly effective and are taken into consideration early (around day 3 of steroid therapy, in the lack of clinical response ${ }^{(1)}$.

- Infliximab as a single dose [5 $\mathrm{mg} / \mathrm{kg}$ ] is another effective salvage therapy in patients with severe ulcerative refractory to intravenous corticosteroids ${ }^{(1)}$.

\section{Clinical cases}

In order to illustrate the heterogeneity of cases of ulcerative colitis, we present briefly three particular situations, with different extension and severity of the disease and, consequently, different therapeutic approach.

\section{Clinical case 1}

- 84 yrs old female;

- Clinical features: diarrhea, abdominal pain, tenesmus;

- Laboratory analysis: $\mathrm{Hb}$ - 11,9 g/dl, white cell count $7.4 \times 10^{9} / /$ with ne utrophilia (68\%) a nd thrombocytosis $\left(424 \times 10^{9} / \mathrm{l}\right)$. ESR was $34 \mathrm{~mm}$ in 1st hr, CRP was $3.08 \mathrm{mg} / \mathrm{dl}$.

- Blood, stool \& urine culture was negative.

- Abdominal ultrasound revealed steatosis.

- Chest X-ray was normal.

- Colonoscopy: edema, erythema and ulcerative lesions located on the rectum, sigmoid and descending colon.

- Histopathologic exam suggestive of ulcerative colitis (infiltration of lymphocytes, polymorphs, eosinophils in the lamina propria, degenerative and regenerative changes).

- Treatment: topical therapy with aminosalicylates combined with oral mesalazine.

- Her symptoms of colitis began to improve after 1 week of treatment.

- In remission after six months.

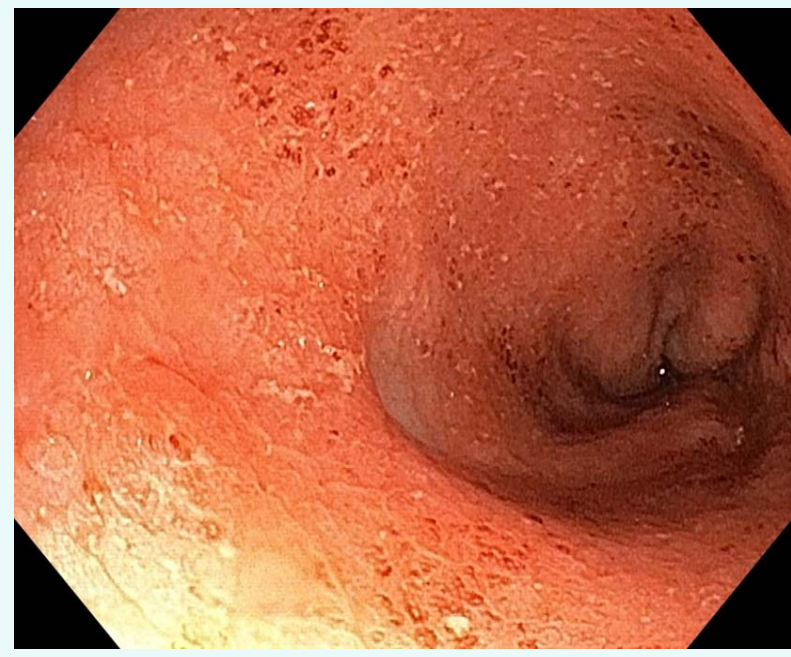

Figure 2. Colonoscopy showing edema, erythema and ulcerative lesions in the rectum

\section{Clinical case 2}

- 18 yrs old girl

- Clinical features: passage of loose bloody stool (4-5 times/day), low grade intermittent fever, abdominal pain with tenesmus and significant weight loss ( $6 \mathrm{~kg}$ in the last 3 months).

- Laboratory analysis: $\mathrm{Hb}-9,1 \mathrm{~g} / \mathrm{dl}$, white cell count $9.2 \times 10^{9} / 1$ with neutrophilia ( $74 \%$ ) a nd thrombocytosis $\left(644 \times 10^{9} / 1\right)$, hypoalbuminemia $(2,4 \mathrm{~g} / \mathrm{dl})$. ESR was $52 \mathrm{~mm}$ in 1st hr, CRP was high (5.12 $\mathrm{mg} / \mathrm{dl})$, fecal calprotectin was high. 


\section{INTERNAL}

Clinical cases

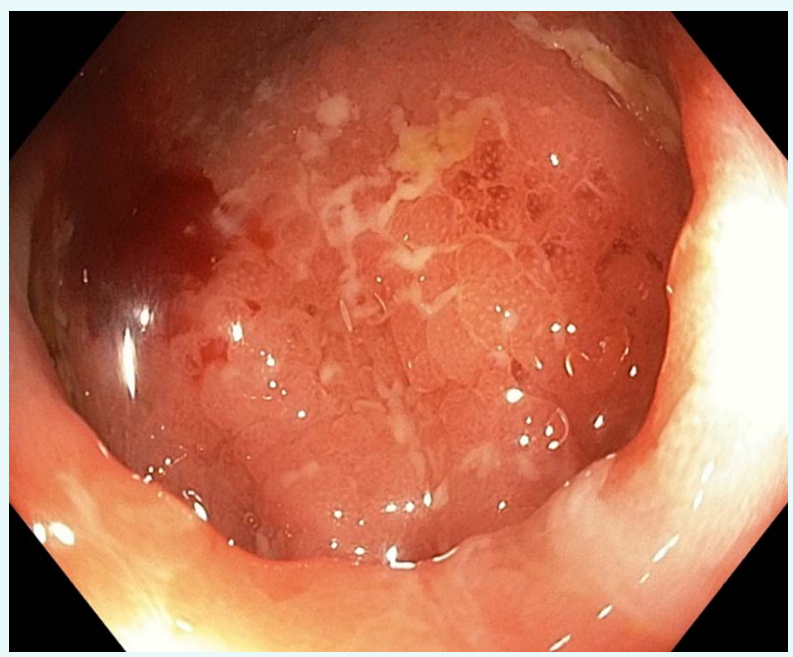

Figure 3. Colonoscopy showing edema, erythema, multiple ulcerative lesions with hemorrhagic surface

- Blood, stool \& urine culture was negative.

- Abdominal ultrasound was normal.

- Chest X-ray was normal.

- Colonoscopy: showed edema, erythema, multiple ulcerative lesions with hemorrhagic surface throughout the entire length of the colon, without ileal involvement.

- Histopathologic exam: surface erosion, increased infiltration of lymphocytes, polymorphs, eosinophils in the lamina propria, degenerative and regenerative changes. Without crypt abscess or granuloma. The findings were suggestive of ulcerative colitis.

- Treatment: injectable hydrocortisone and oral mesalazine were given.
- After one week of treatment, her symptoms of colitis seemed to improve and subsequently she was discharged home on prednisolone and meselamine.

- However, the number of stools remained increased, and after the withdrawal of corticosteroids, the stools become once again bloody, so that the patient required the early introduction of anti-TNF alpha therapy.

\section{Clinical case 3}

- 28 yrs old man;

- Clinical features: passage of loose bloody stool (more than 10 times/day), low grade intermittent fever, abdominal pain and significant weight loss (5 kg in the last 6 weeks).

- Laboratory analysis: $\mathrm{Hb}-7,5 \mathrm{~g} / \mathrm{dl}$, white cell count $10.6 \times 10^{9} / 1$ with neutrophilia (74\%) and thrombocytosis (504 $\left.\times 10^{9} / l\right)$, hypoalbuminemia $(2,8$ $\mathrm{g} / \mathrm{dl}$ ). ESR was $48 \mathrm{~mm}$ in $1 \mathrm{st} \mathrm{hr}, \mathrm{CRP}$ was high (18.24 mg/dl), fecal calprotectin was high.

- Blood, stool (including Clostridium difficile GDH and toxins) \& urine tests were negative.

- Abdominal ultrasound was normal.

- ChestX-ray was normal.

- Colonoscopy: showed edema, 


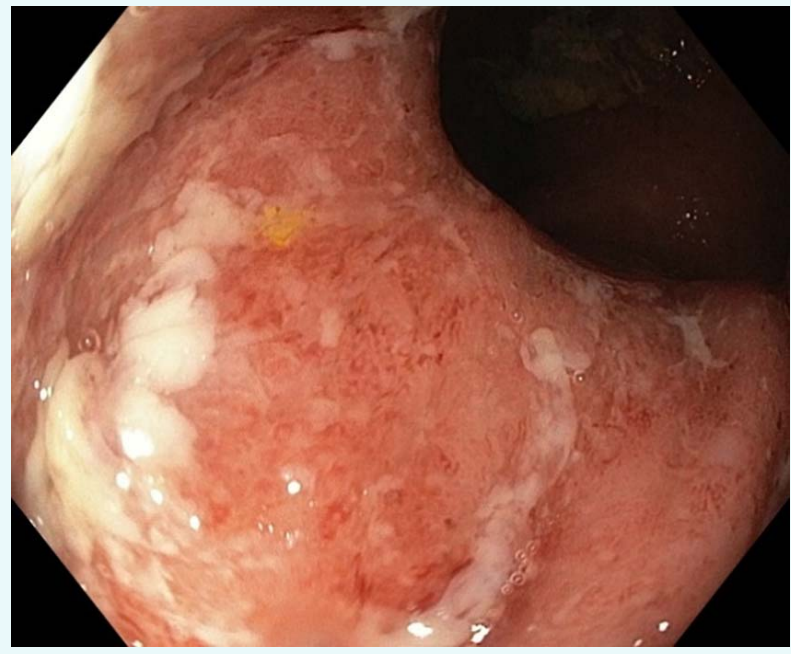

Figure 4. Colonoscopy showing edema, edema, erythema, multiple deep ulcerative lesions with hemorrhagic surface

erythema, multiple deep ulcerative lesions with hemorrhagic surface throughout rectum, sigmoid and descendent colon, where the procedure was stopped concerning the risk of perforation.

- Histopathologic exam: surface erosion, increased infiltration of lymphocytes, polymorphs, eosinophils in the lamina propria, degenerative and regenerative changes. Without crypt abscess or granuloma. The findings were suggestive of ulcerative colitis. We excluded the presence of cytomegalovirus infection by histopathologic exam and anti cytomegalovirus antibodies type IgM.

- Treatment: injectable hydrocortisone and oral mesalazine were given, with no clinical response.

- After three days of treatment, the stools remained bloody and increased in number (10/day), $\mathrm{Hb}$ value was 7,2 despite two units of blood given in transfusions, ESR was $42 \mathrm{~mm}$ and CRP was high $(21,14 \mathrm{mg} / \mathrm{dl}$
- To avoid proctocolectomy, we decided the early introduction of anti-TNF antibodies (Infliximab $5 \mathrm{mg} / \mathrm{kg}$ );

- After the first administration of the drug, the symptoms of colitis improved, and laboratory tests improved also in the following days.

- Colonoscopy showed the healing of the ulcerations and multiple regenerative pseudopolips throughout the entire length of the colon.

- After completing the induction scheme, the patient continues anti TNF alfa therapy and remains in remission during the next 6 months (until present date).

\section{References}

1. Third European Evidence-based Consensus on Diagnosis and Management of Ulcerative Colitis. Part 1: Definitions, Diagnosis, Extra-intestinal Manifestations, Pregnancy, Cancer Surveillance, Surgery, and Ileo-anal Pouch Disorders, Journal of Crohn's and Colitis, Volume 11, Issue 6, 1 June 2017, Pages 649-670)

2. Second European evidence-based consensus on the diagnosis and management of ulcerative colitis Part 2: Current management, Journal of Crohn's and Colitis (2012) 6, 991-1030

3. Christian Maaser at all, ECCO-ESGAR Guideline for Diagnostic Assessment in IBD Part 1: Initial diagnosis, monitoring of known IBD, detection of complications, Journal of Crohn's and Colitis, Volume 13, Issue 2, 1 February 2019, Pages 144-164K

4. Truelove SC, Witts LJ. Cortisone in ulcerative colitis; final report on a therapeutic trial. $\mathrm{Br}$ Med J 1955;2:1041-8.

5. Silverberg MS, Satsangi J, Ahmad T, et al. Toward an integrated clinical, molecular and serological classification of inflammatory bowel disease: report of a working party of the 2005 Montreal World Congress of Gastroenterology. Can J Gastroenterol 2005;19:5A-36A 6. Orlando A. et all. The Italian Society of Gastroenterology (SIGE) and the Italian Group for the study of Inflammatory Bowel Disease (IG-IBD) Clinical 
Clinical cases

Practice Guidelines: The use of tumor necrosis factoralpha antagonist therapy in inflammatory bowel disease. Dig Liver Dis. 2011;43:1-20.

7. Danese S. et all. Causative factors and the clinical management of patients with Crohn's disease who lose response to anti-TNF- $\alpha$ therapy. Aliment Pharmacol Ther. 2011;34:1-10

8. Imdad A, Nicholson MR, Tanner-Smith EE, Zackular JP, Gomez-Duarte OG, Beaulieu DB, Acra S. Fecal transplantation for treatment of inflammatory bowel disease. Cochrane Database of Systematic Reviews 2018, Issue 11. Art. No.: CD012774

9. Ingrid Ordás et al, Ulcerative colitis, The Lancet,
Volume 380 , Issue 9853, $1606-161$

10. Sleisenger and Fordtran's, Gastrointestinal and liver disease, Saunders, Elsevier 2010

11. American College of Gastroenterology, Ulcerative Colitis in Adults, AmJ Gastroenterol 2010; 105:501-523

12. Clinical Practice Guidelines for the Medical Management of Nonhospitalized Ulcerative Colitis: The Toronto Consensus, Gastroenterology 2015; 148:1035-1058

13. D'Haens G, Sandborn WJ, Feagan BG, et al. A review of activity indices and efficacy end points for clinical trials of medical therapy in adults with ulcerative colitis. Gastroenterology 2007;132:763-86 